\title{
Effective Communication Training to Improve the Satisfaction of Wedding Marriage / Long Distance Marriage (LDM) Review Marriage Commitments from Marriage Commitment
}

\author{
Lulus Faqihatur Rohmah; IGAA Noviekayati; Sahat Saragih \\ Professional Psychology Study Program, Universitas 17 Agustus 1945 Surabaya, Indonesia \\ http://dx.doi.org/10.18415/ijmmu.v7i8.1947
}

\begin{abstract}
This study aims to improve marital satisfaction, communication and marriage commitments to wives who undergo long distance marriage in Indonesia Malaysia. Data was taken from 33 Subjects, and scoring and entering categories. A total of 15 mothers have low to very low marital satisfaction, communication and commitment to marriage. However, only 12 Subjects were willing to take effective communication training until completion. The training provided is effective communication training to improve marital satisfaction, communication and marriage commitments. The subjects of effective communication training are mothers who live in Serah Panceng Gresik Village, aged 23-45 years and have a marriage age of 6-26 years and have 1-2 children. Most work as housewives and have an average high school education. This research is an experimental research. The experimental design used was a one group design in the form of One group pretest-posttest design. Data analysis using the Independent Sample t-test and Product Moment. The results of the first hypothesis significance level of $0,000<0.01$, which means that there are significant differences in both communication and marriage satisfaction before and after training is given. The second hypothesis is the significance level of $0.026<0.05$, which means there is a positive relationship between communication and marital satisfaction. The third hypothesis is the significance level of $0.018<0.05$, which means there is a positive relationship between marriage commitment and marital satisfaction.
\end{abstract}

Keywords: Marriage Commitment; Communication; Marriage Satisfaction

\section{Introduction}

Marriage is a bond of birth and mind, which means that in marriage both of these things must really exist. Inner bonds are bonds that are not directly visible. Inner bonding is a psychological bond, a married couple must love one another, and there is no coercion in marriage. Both of these bonds, namely the bond of birth and inner bond are required to exist in marriage. If there is no one, it will cause problems in the couple's life (Walgito, 2017). Every husband and wife generally expect to stay together in one house every day, but this cannot be realized because there are several factors that make them unable to live in the same house. One form of long-distance marriage is when one spouse must become an 
Indonesian migrant worker (TKI) abroad (Gufron \& Suminta, 2017). Long distance marriages are not easy to live, especially for a wife. Wives left by their husbands to work for long periods of time will be exposed to various risks that may occur in their marital relationships, especially for couples who already have children. These risks can be in the form of a relationship that is not harmonious, frequent fights, feelings of suspicion and worries and fears that can sometimes be one of the factors that can trigger household noise. Marriage satisfaction that is felt by wives undergoing long-distance relationships is not necessarily the same as wives who meet with their husbands every day and live together, let alone many factors that can influence marital satisfaction (Handayani, 2016).

Misunderstanding in communication can lead to conflict, problems that often occur in communication occur because of using negative communication styles (Lestari, 2012). Couples who undergo long distance marriage naturally face different problems with married couples who live together. More important in communication problems between couples compared with those who live in the same house (Rachmawati \& Mastuti, 2013). According to Rachmat (in Widyanisa, et al, 2018) that interpersonal communication will lead to five things in the life of a married couple, namely mutual understanding, feelings of pleasure, influence on attitudes, better relationships, and actions on couples. Married couples who undergo Long Distance Marriage cannot communicate directly face to face because of the distance so they can only express their feelings through verbal communication in the form of praise, but cannot be realized by direct touch.

In general, commitment to relationships can make someone feel more satisfied with the relationship. Commitments to long-distance marriages tend to be highly valued by couples who successfully negotiate. Success in long distance marriages is based on a strong commitment to marriage and partners (Naibaho \& Virlia, 2016). Researchers have conducted interviews on December 5 to 2018 to several subjects. The results obtained from the interview show that subjects A, AN, S, E and B are quite satisfied and some are less satisfied in their marriages. They say that communication, commitment and several other factors are very important in undergoing long distance marriage. Long distance relationships keep couples unable to meet every day, so communication is more often done using social media. There are so many conflicts in the family that sometimes even more severe when communicating through social media, causing misunderstandings and making husband and wife relationships become problematic.

One subject told how the problems faced by a wife undergoing a long distance marriage. Communication problems to feelings of feelings felt by the wife when far apart with her husband. Communication problems occur when the husband is busy working and the wife wants to tell the problem or just want to hear the husband's voice because of longing. This has become a problem. Before marriage, most of the men in the area worked as Indonesian workers (TKI), so the wives were ready to undergo long distance marriage. In fact, some of them said that her husband only came home once a year at the Eid. However, there are also many husbands who do not go home during Eid due to various reasons, for example they do not get Lebaran permission, there are still many jobs, there is not enough money, or other problems. The lack of commitment makes the wife and husband undergoing long distance marriage feel dissatisfied in marriage. They even look for another ideal woman or another ideal man to fulfill the satisfaction they are lacking in marriage. Subject B said that the commitment to increase marital satisfaction must be really strong. Subject B is one of the wives who experiences unpleasant things in their marriage. The presence of another woman made her marriage on the edge. Based on the phenomenon described above. 


\section{Marriage satisfaction}

According to Hurlock (in Anindya \& Soetjiningsih 2017) Marriage satisfaction is the level of success of a married couple in dealing with and adjusting in marriage as well as problems that occur in domestic life. Fowers and Olson (in Anindya \& Soetjiningsih 2017) suggested that marital satisfaction is a feeling related to aspects in a marriage, where these feelings are subjective feelings, such as feelings of satisfaction, happiness, and also experiences with a partner who a lot of fun. The aspects raised by Olson that refer to the ENRICH Marital Satisfaction Scale are due to the more specific aspects related to marital satisfaction and several other studies also refer to aspects developed by Olson, namely communication, flexibility, closeness, personality match , conflict resolution, sexual relations, leisure activities, family and friends, financial management and spiritual beliefs.

\section{Effective Communication}

Effective communication according to Hadjana (in Syagitta, et al, 2017) includes communication carried out both verbally and non-verbally. Effective communication has characteristics, namely clear and concise, words easily understood, have denotative and connotative meanings, intonation has the right tempo and pause, so as to make the contents of the message easy to understand, and the humor component in it. The effectiveness of interpersonal communication if explained from the perspective of The 5 inevitable of laws of effective communication or five effective communication laws include five aspects abbreviated as REACH which include Respect, Empathy, Audible, Clarity, and Humble. This is relevant to the principle of interpersonal communication that is as an effort to gain attention, recognition, love, and appreciation for themselves from the social environment.

\section{Marriage Commitment}

Commitment to marriage is a subjective experience of a person in his household, where a couple tries to keep and maintain a marriage even in a difficult or happy situation. The husband and wife realize that morally they must survive in the household. Marriage commitment consists of three aspects, namely personal commitment, moral commitment and also structural commitment (Johnson in Amelia, et al, 2018).

\section{Research Method}

The research method used in this research is experiment. Experimental research is research conducted by providing manipulation. The design of this research is experimental design research. The experimental design used was a one group design in the form of One group pretest-posttest design. According to Christensen (in Seniati, et al, 2018) One group pretest-posttest design is also called beforeafter design. In this design, measurements are made before giving treatment (Pretest) and after being given treatment (Posttest).

\section{Research Subject}

The subject of this study was a wife who underwent a long distance marriage (LDM) with her husband who was an Indonesian worker (TKI) in Malaysia and resided in the village of Serah Panceng Gresik. 


\section{Data Analysis}

The researcher used the parametric statistical t-test independent sample (Independent Sample ttest) to test the significance of differences in the level of marital satisfaction and effective communication before and after effective communication training was given. Meanwhile, the statistical technique used in correlation analysis in this study uses Product Moment Correlation. Product Moment is one of the techniques developed by Karl Pearson to calculate the correlation coefficient. The purpose of Product Moment is to find a relationship between the independent variable (X) with the dependent variable (Y) and the ratio data (Sutrisno, 2014).

\section{Results}

The first hypothesis, namely effective communication training (KE) is effective for increasing marital satisfaction. Based on the calculation of the Independent Sample t-test to determine differences in marital satisfaction before and after effective communication training is given. At the equal variance assumed the significance level of 0.000 is obtained. These results indicate that $p<0.01$, meaning there are differences in marital satisfaction before and after effective communication training is given. Based on the calculation of the Independent Sample t-test to determine the difference between effective communication before and after effective communication training is given. At the equal variance assumed the significance level of 0.000 is obtained. These results indicate that $p<0.01$, meaning there are differences in effective communication before and after effective communication training is given.

The second hypothesis is that there is a positive relationship between effective communication (X1) and marital satisfaction (Y). Based on data analysis, shows the correlation coefficient $(\mathrm{r})=0.637$ with a significant value $(\mathrm{p})=0.026$, because the significance level obtained is less than $0.05(0.026$ $<0.05)$, then there is a significant or positive correlation between the effective communication variables (X1) with marital satisfaction (Y). These results indicate that there is a strong, positive and significant relationship between effective communication (X2) and marital satisfaction (Y). Means the higher the communication, the higher the marriage satisfaction. Conversely, the lower the communication, the lower the marriage satisfaction for wives undergoing long distance marriage. The third hypothesis is that there is a positive relationship between marital commitment (X2) and marital satisfaction (Y). Based on data analysis, it shows a correlation coefficient $(r)=0.667$ with a significant value $(p)=0.018$, because the significance level obtained is less than $0.05(0.018<0.05)$, then there is a significant or positive correlation between marital commitment variables and marital satisfaction. These results indicate that there is a strong, positive and significant relationship between marital commitment (X2) and marital satisfaction. Means the higher marriage commitment, the higher marriage satisfaction. Conversely, the lower the marriage commitment, the lower marriage satisfaction for wives undergoing long distance marriage.

\section{Discussion}

The results of the first hypothesis test from this study indicate that there are significant differences in the level of communication and also the level of marital satisfaction before and after effective communication training is given. This means that effective communication training (KE) is effective in increasing marital satisfaction for wives undergoing long distance marriage (LDM). Effective communication can occur if in a communication produces the same view between the recipient of the message and the sender of the message, so there is no misunderstanding or has a different meaning. Communication skills are the ability to convey a message to be conveyed. If the communication between partners has good quality, then the couple can feel closer to each other. Sharing feelings and thoughts, can feel more intimate and good communication can prevent misunderstanding that usually often occurs in 
domestic life, so that couples can feel more together and enjoy happin ess. Therefore, communication can be said to be the center of a marriage. The ability to communicate is a major factor in the satisfaction of marital relations. Communication training aims to improve the relationship of husband and wife, can handle difficult situations and make relationships better, and make mental health, physical and social life better. The importance of communication must be explained to married couples, in the hope that the influence of communication skills can impact on increasing marital satisfaction. This can help married couples be happier and more satisfying, it can also help in minimizing or solving problems between married couples (Lundblad \& Hansson in Haris \& Kumar, 2018).

The existence of an empathy attitude to the husband when the husband is in a condition or situation that is not good. The wife must understand and be able to place themselves when the husband needs it. Listening to a husband without criticizing the speaker is an attitude of empathy that can be shown to the husband, especially when establishing a long distance marriage. The wife listens first to the husband's complaints when there are problems regarding work or family, then gives a good response or gives good words to the husband so that the husband is calmer. Listen and understand well, where the message delivered will be well received by the recipient, so there are no misunderstandings. Couples who undergo long distance marriage can only use social media or telephone to communicate, so good cooperation is needed between the two. The contents of a message must be clear and not cause misinterpretation. In long distance marriage, many things can affect misunderstandings in communication, so it requires openness between the two.

The results of the second hypothesis test indicate that there is a significant relationship between effective communication and marital satisfaction. There is a positive relationship between communication and marital satisfaction. Where, communication is one of the factors that can influence the level of satisfaction of married couples, especially couples who undergo long distance maariage (LDM). Verbal and non-verbal communication play an important role in domestic life, especially if they cannot meet every day because of work demands.

Based on research conducted by Paramitha \& Suarya (2018) it can be concluded that communication has a very important role in marital satisfaction in women in middle adulthood. Communication has a significant role in marital satisfaction in women in middle adulthood. The results of this study support previous research. Based on the results obtained from research conducted by Dewi \& Sudhana (2013), interpersonal communication between married couples is a factor that gives influence to marital satisfaction. The results of the analysis have been conducted, researchers get the results of a positive relationship between interpersonal communication between married couples with marriage satisfaction.

From the results of this study, marital satisfaction can be improved through effective communication, where communication is one of the most important factors in marital satisfaction. The most important factors of marital satisfaction are good communication between husband and wife, especially to couples who undergo long distance marriage, where they cannot meet every day. Communication is done only through social media or telephone, so it must really be able to make effective communication to avoid misunderstandings between the two. Using social media can facilitate communication, especially if you can find out at any time your husband is abroad. Communication that cannot be done properly will create and increase conflict in the household.

The third hypothesis test results from this study is that there is a significant relationship between marital commitment and marital satisfaction. There is a significant and positive relationship between marriage commitment and marriage. Where, marriage commitment is one of the factors that can also affect the level of marital satisfaction of married couples, especially married couples who undergo long distance mariage (LDM). 
Commitment is one of the most important factors in marital satisfaction. Commitment is needed to keep the marriage going, both in good condition and in unfavorable conditions. Commitments that are built very strong will make the marriage strong and the married couple will get satisfaction in marriage. Commitment is very influential on marital satisfaction, especially in wives undergoing long distance marriage (LDM). From the results of this study, marital commitment occurs due to several aspects, namely structural, moral and personal, where children are one of the main factors to maintain marriage, children will not be sacrificed for their own pleasure. So also with the economic life of a wife, a wife who does not work will find it difficult when separated from her husband. Families who do not support separation are another factor for the wife to survive. The amount of time spent together, makes a wife who underwent long distance marriage to maintain her marriage even though sometimes it can no longer stand. The subject feels obliged to continue any relationship that is happening for the sake of the family and many other factors that make it last.

Positive changes in marital satisfaction can be seen in the difference in scores before and after training. Before being given training, the level of marital satisfaction at wives undergoing long diatance mariage falls into the very low category, then after being given effective communication training, the level of marital satisfaction increases to an average of medium to high categories. This can also be seen in each of the effective communication scores and also in the marriage commitment score after being given effective communication training. Before being given training, both communication and commitment to marriage have a low and very low score, after being given training, the level of communication and marriage commitment on average becomes a moderate to very high score. Subjects experienced a change in score that rose significantly so that there was an increase in both marital satisfaction, communication and marriage commitment.

\section{Conclusion}

Based on the results of research and discussion in research. In the first hypothesis, it can be concluded that there are differences in communication and marital satisfaction before and after effective communication training is given. This means that effective communication training (KE) is effective in increasing marital satisfaction for wives undergoing long distance marriage (LDM). This result can be seen from the increase in both communication and satisfaction of marriage itself.

\section{References}

Adi, W.Y., \& Lestari, M.D. (2019). Gambaran komitmen dalam pernikahan pasangan remaja yang mengalami KTD. Jurnal Psikologi Udayana, 6 (1): 805-81.

Amelia,R.,Abidin, Z., \& Riskasari, W.(2018). Hubungan Antara Self Disclosure dan Religiusitas Dengan Komitmen Pernikahan Pada Istri Pelaut Tni-Al. Jurnal Ilmiah Psikologi Kelautan-Kemaritiman, 12 (01).

Anindya, A. S., \& Soetjiningsih, C. H. (2017). Kepuasan Perkawinan dengan Kesejahteraan Subjektif Perempuan dengan Profesi Guru Sekolah Dasar. Insan Jurnal Psikologi dan Kesehatan Mental, 2 (1) $42-50$.

Babaee, S.N., \& Ghahari, S. (2016). Effectiveness of communication skills training on intimacy and marital adjustment among married women. International Journal of Medical Research \&Health Sciences, 5 (8):375-380.

Dewi, N.R., \& Sudhana, H.(2013). Hubungan Antara Komunikasi Interpersonal Pasutri dengan Keharmonisan dalam Pernikahan. Jurnal Psikologi Udayana, 1 (1): 22-31. 
Ghufron, M. N., \& Suminta, R. R. (2017). Komitmen Beragama dan Kepuasan Perkawinan pada Pasangan yang Bekerja Menjadi Tenaga Kerja Indonesia. Psikohumaniora Jurnal Penelitian Psikologi, 2 (2): 143 - 157.

Handayani, Y. (2016). Komitmen, Conflict Resolution, dan Kepuasan Perkawinan pada Istri yang Menjalani Hubungan Jarak Jauh( Karyawan Schlumberger Balikpapan). Psikoborneo, 4 (3): 518 529.

Harahap, S.R., \& Lestari, Y. I. (2018). Peranan komitmen dan komunikasi interpersonal dalam meningkatkan kepuasan pernikahan pada suami yang memiliki istri bekerja. Jurnal Psikologi, 14 (2): 120-128.

Lestari, S. (2012). Psikologi Keluarga. Jakarta : Prenada Media Group.

Paramita, N. K. P., \& Suarya, L. M. K. S. (2018). Peran Komunikasi Interpersonal dan Ekspresi Emosi Terhadap Kepuasan Perkawinan pada Perempuan di Usia Dewasa Madya. Jurnal Psikologi Udayana, 5 (2): 241-253.

Rubyasih, A. (2016). Model komunikasi perkawinan jarak jauh . Jurnal Kajian Komunikasi, 4(1): 109 119.

Seniati, L., Yulianto, A., \& Setiadi,B. N. (2018). Psikologi Eksperimen. Jakarta: PT. Indeks.

Syagitta, M.,Sriati, A., \& Fitria, N. (2017). Persepsi Perawat Terhadap Pelaksanaan Komunikasi Efektif di IRJ Al-Islam Bandung. Jurnal Keperawatan BSI, V(2).

Tavakolizadeh, J., \& Nejatian, M. (2015). The Effectiveness of Communication Skills Training on Marital Conflicts and its Different Aspects in Women. Procedia-Sosial and Behavioral SciencesVolume, 17(1): 214-221.

Tomy Michael, Right to Have Rights, Mimbar Keadilan Jurnal Ilmu Hukum, februari 2017.

Tomy Michael, Memaknai Pemikiran Jean-Jacques Rousseau Tentang Kehendak Umum Menciptakan Keadilan.

Walgito, B. (2017). Bimbingan \& Konseling Perkawinan. Yogyakarta :C.V Andi Offset.

Widyanisa, A., \& Lubis, H. (2018). Pola komunikasi interpersonal pada pasangan suami istri yang menjalani long distance marriage (studi kasus pada karyawan pt. pertamina persero kota balikpapan). eJournal Ilmu Komunikasi, 6 (4): 385 - 397.

\section{Copyrights}

Copyright for this article is retained by the author(s), with first publication rights granted to the journal.

This is an open-access article distributed under the terms and conditions of the Creative Commons Attribution license (http://creativecommons.org/licenses/by/4.0/). 